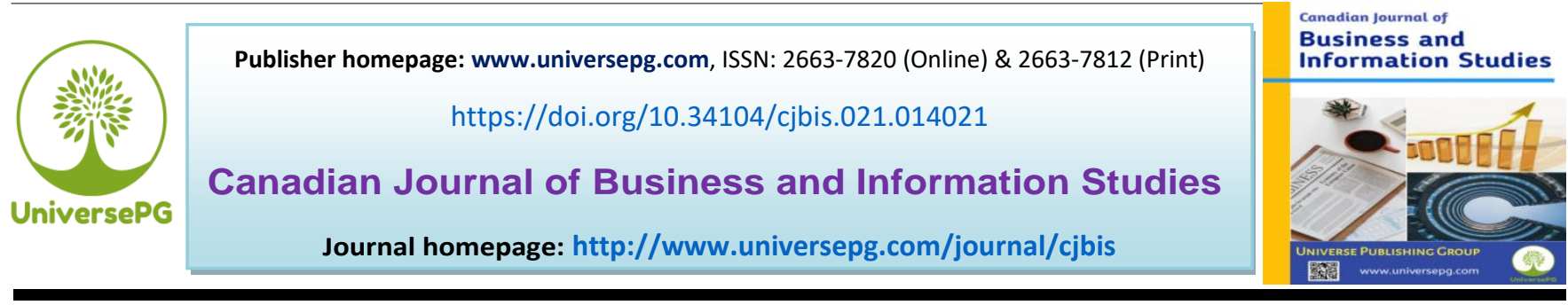

\title{
Assessment of the Heterogeneity Influencing the Superior of Non- Banking Finance Company for Assisting Consumer Durable Loans
}

\author{
Md. Saifullah Khalid ${ }^{1 *}$, Arvind Hans², Mst. Sadia Arefin ${ }^{3}$, and Md. Rasel Hossain ${ }^{4}$ \\ ${ }^{1}$ Dept. of Commerce and Business Management, Ranchi University, Jharkhand, India; ${ }^{2}$ Faculty of Business Management and \\ Commerce, Usha Martin University, Jharkhand, India; ${ }^{3}$ Dept. of Business Administration, Gono Bishwabidyalay, Savar, \\ Dhaka, Bangladesh; and ${ }^{4}$ Dept. of Statistics, Noakhali Science and Technology University, Noakhali, Bangladesh. \\ *Correspondence: saif.kh92@ gmail.com (Md.Saifullah Khalid, Assistant Professor, Department of Commerce and Business \\ Management, Ranchi University, Ranchi, Jharkhand, India).
}

\begin{abstract}
Customers purchasing behavior has changed radically in the course of the most recent couple of years. The study aimed to identify major factors determining consumer's choice rules of the non-banking financial company (NBFC) for availing consumer durable loans (CDLs). Essential information was gathered from 100 respondents by utilizing a survey including eight factors, recognized dependent on an audit of writing. Principal Component Analysis (PCA) was utilized as an extraction strategy by utilizing factor analysis. Three factors were isolated by using Eigenvalues standards and these three factors were assigned names such as service delivery, terms \& conditions, and safety and security of fund respectively. It was suggested from the study that the non-banking financial companies aimed to expand their business should take cognizance of these factors in their marketing strategies.
\end{abstract}

Keywords: PCA, Durable loan, NBFCs, Selection criteria, Principal component method, and Factors analysis.

\section{Introduction}

With a simple admittance to banking administrations and accessibility of credit, they like to buy merchandise on credit. The purchase of durable goods on finance has increased to 55 percent. Individuals are updating their buys with the compensation of simple financing alternatives raising the customer bill value. General monetary incorporation has been a need on the approach plan of the administration according to the census 2011, only 59\% of total households availed banking services, with $67.8 \%$ and $54.4 \%$ in urban and rural areas respectively. The financial stability report (FSR) of RBI, (2014) noted that NBFCs could play a major role in supporting the efforts towards financial inclusion in India. They are, in effect, contributing immensely to financial inclusion by stretching out credit to the unbanked populace of the nation (Ray et al., 2018).

\subsection{Consumer durable goods (CDGs)}

While there is no universal definition of CDGs, hitherto it can be defined as goods that last for a longer time (durable goods, n.d.). They include consumer electronics or brown goods (such as television, laptops, digital cameras, electronic accessories, etc.) and consumer appliances or white goods (such as air conditioners, refrigerators, washing machines microwave oven, electric fans, etc. (IBEF, 2018). 


\subsection{Consumer loans}

Consumer loan is a type of loan given to an individual on a non-secured basis for distinctive and family expenses. These loans are given for a shorter period generally from 1 year to 3 years (Ray et al., 2019). The majority of the shopper advances are utilized to fund expenses on vehicles and customer durables and are unstable with no insurance for security to the loaning banks (Mahmud and Rahman, 2020). The study has zeroed in on distinguishing the elements dependent on which clients settle on a choice to take the loan.

\section{Literature review}

\subsection{Growth and size of durable loan market}

Consumer durable market (CDM) is growing very fast and is assessed to be Rs. 1 trillion (US\$ 15.5 billion) in size. Two third of the durable products sales income is produced from the urban market while the rest 33\% of the equivalent is created from the local market. It is also observed that, during the carnival season such as Diwali \& Dhanteras, sales of refrigerators, television, and washing machines upsurges. Various players are working in the customer durable industry. Some of the recognized names are Godrej, Mirc Electronics, Blue Star and Videocon, etc. In the course of the most recent couple of years, the CDM has pulled in significant investment. The policy support given by the government of India has also given a fillip to the industry. 100 percent FDI is allowed in electronic hardwares, parts manufacturing under the automated route. The endorsement of 51 percent FDI in multibrand retail would additionally animate the business' development (IBEF, 2018).

Studies exposed that the greater part of the respondent knew about the accessibility of CDLs for items, such as TVs, cell phones, home apparatuses, PCs, and so on (Ray et al., 2018). Consumers are shifting their preferences to no cost or zero cost finance from NBFCs. They are favoring paying through credit cards in place of cheques (Ray \& Mukherjee, 2019). They prefer NBFCs to banks because of their fast and prompt service and expertise in niche segments (Ray et al., 2018). Some of the known NBFCs giving CDLs are Bajaj Finserv, Tata Capital, HDFC, Dena Bank, and Home credit (Top 5 NBFCs, 2018). Home Credit has retained the number one position in small-ticket CDLs ("Home Credit", 2018).

\subsection{Factors of selection criteria of banks/NBFCs}

A few examinations contemplates directed on the choice measures affecting the selection of banks/ NBFCs for CDLs. An attempt has been made to analyze such studies to explain and identify major factors determining the loan decisions. Allaire, (1972) conducted a study on marketing thoughts on competition between banks and near banks in Canada. The study explicated that convenience, security, bank personnel, and interest rate were key determinants in pick out a bank. Laroche et al. (1986) examined the significant factors in picking a bank in Canada. The study revealed that location, speed of service, competence, and friendliness of employees were considered significant for choosing the bank. Similarly, Erol et al. (1990) led a study on cookies of conventional and Islamic banks in Jordan. It was found that confidentiality was a major determinant in selecting banking services. Further, Haron et al. (1994) studied 301 cookies of Islamic and non-Islamic commercial banks in Malaysia. The study established that fast and efficient services, speediness of transactions, and responsiveness of bank staff along with confidentiality were key reasons for selecting Islamic and non-Islamic commercial banks (Hoque et al., 2020; Amin, 2020).

Holstius and Kaynak, (1995) surveyed 258 bank customers in Finland. It was established that customer service, service quality, the bank's personnel openness, and confidentiality were the key patronage factors affecting customer decision to choose a bank. Boyd et al. (1994) led a survey on younger bank cookies to decide their determination standards for picking a bank. It was discovered that the youthful people gave more significance to elements, such as bank reputation, location, operating hours, interest rates, and convenience of operation for pick out a bank. Almossawi, (2001) pursued a study on college students in Bahrain shown that suggestions from companions and family members were the foremost reasons for pick out a bank.

Kamakodi and Khan, (2008) conducted a study on 292 new generation private sector bank cookies to decide the components that impact the evaluation standards of 
a bank. The investigation recognized safety of assets, secured ATMs, ATMs accessibility, reputation, individual consideration, satisfying habits, confidentiality, closeness to duty, convenient help and friendly staff, and ready to work were the significant measures for credit choices.

Rehman and Ahmed, (2008) studied 358 cookies of private and public sector banks in Pakistan. It was set up those client administrations, comfort, internet banking interests, and gross bank environment were key indiators for pick out a bank. Rao and Sharma, (2010) pursued a study on 312 young students in India. The study focused that representative's kind-ness, parking facility, loyalty programs, brand name, security framework, low charges, responsiveness, valueadded services; convenience, speedy services, and good rate of interest were significant criteria for preference of bank. Hedayatnia and Kamran, (2011) led a survey on 798 bank purchasers in Iran. The study disclosed that the nature of administrations, new banking techniques, development and responsiveness of bank, cordiality of staff, trust in chief, price and cost, staff mentalities, and satisfaction of bank area and services were key factors for pick out a bank for taking credits.

Junior et al., (2013) studied 300 bank cookies in Ghana to examine the key reasons for pick out a bank. The cookies were selected from five nationalized banks such as Agricultural Development Bank (ADB), Ghana Commercial Bank (GCB), Societe Generale Bank (SGB), Barclays Bank, and Kaaseman Rural Bank (KRB). Study inferred that occupation and safety of deposit were significant factors for settling on retailbanking choices. Study conducted by Singh et al., (2013) on 225 individuals, further established that marketing activities, selling activities, use of modern technology, service quality, and atmospherics were significant components considered for pick out a bank.

Rahaman et al., (2015) conducted a study on 174 cookies divided into three broader categories via bank executives, borrowers, and depositors of Bangladeshi commercial banks to conclude the key indicators used for selecting their bank. A study showed borrowers gave more significance to components, such as diversified financial administrations, the acclaimtion of the bank, physical facilities, immediacy in banking, commercial while choosing their bank. However, the bank executives considered reliability and cookie friendliness, physical interests and cash management service, financial interest and charges, mobile banking area, and ATM service were more important for attracting cookies to their banks.

Aliero et al. (2018) found that monetary factors such as interest rate, the protection of funds, and availability of credits were important reasons. It was further established that image, reputation, and service performance of the bank were also very important determinants for selecting any bank for CDLs. It can be proved from the various literature review that bank/ NBFCs selection criteria vary across geographical locations and different types of cookies. Some of the important variables or indicators identified through the above literature review were loan conditions, interest rates, insurance, guarantee, installment, shop design, and processing and employee behavior. In light of the review, the present search incorporated eight important criteria to investigate their influence on the druthers of NBFCs for loan decisions (Akter, 2020).

\section{Need and significance of the work}

Regardless of the truth that there were a few examinations led on the decision rules of a commercial bank, up to now there is a paucity of research studies pursued in the Indian context highlighting the major factors influencing loan decisions in NBFCs. This work is an endeavor to distinguish identify those factors and recommend policies expected to improve the marketing efforts of NBFCs.

\section{Research objectives}

The main objectives of the present research are -

1) To identify the determinants/variables affecting the decision of NBFCs for availing CDLs.

2) To propose a framework for further study based on the research findings.

3) To identify the important key factors/dimensions using principal factor analysis through factor analysis. 


\section{Design of the Research model}

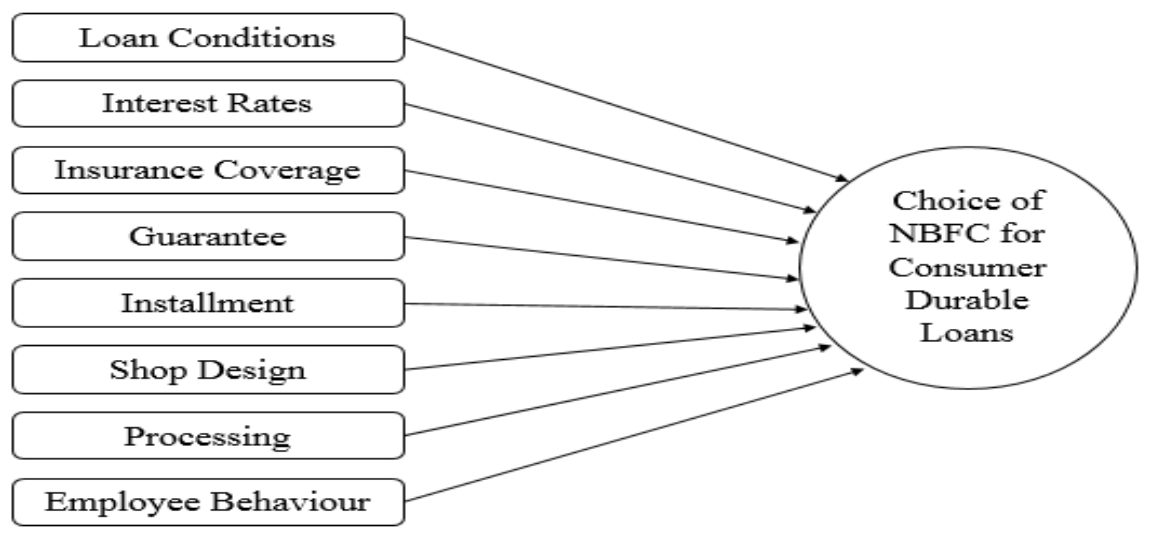

Fig 1: Choice of NBFC for CDLs.

\section{METHODOLOGY:}

Investigational work was conducted to identify variables influencing the selection of NBFC for CDLs. A self-designed questionnaire using a 5-point Likert scale was constructed by incorporating eight variables based on the evaluation of the literature. The items used in the scale were anchored by very important to very unimportant. The survey was con-ducted by administering the questionnaire on 140 consumers who intended to take consumer credits at any point in time. Only, 100 fully completed responses were obtained. The data taken was edited, coded, tabulated, and analyzed by using SPSS software. A reliability test was pursued to check the internal consistency among the variables. Table 1, showed that the Cronbach's alpha coefficient was 0.729 , which indicated that the scale used was reliable.

Table 1: Reliability test

\begin{tabular}{|c|c|c|}
\hline \multicolumn{3}{|c|}{ Reliability Statistics } \\
\hline $\begin{array}{c}\text { Cronbach's } \\
\text { Alpha }\end{array}$ & $\begin{array}{c}\text { Cronbach's Alpha } \\
\text { Based on Standardized } \\
\text { Items }\end{array}$ & N of Items \\
\hline .729 & .739 & 8 \\
\hline
\end{tabular}

\section{Data analysis and interpretation}

Table 2: Sampling adequacy test

\begin{tabular}{|c|c|c|}
\hline \multicolumn{3}{|c|}{ KMO and Bartlett's Test } \\
\hline \multicolumn{2}{|c|}{$\begin{array}{c}\text { Kaiser-Meyer-Olkin Access of } \\
\text { Sampling Adequacy. }\end{array}$} & .637 \\
\hline \multirow{3}{*}{$\begin{array}{c}\text { Bartlett's } \\
\text { Test of } \\
\text { Sphericity }\end{array}$} & Approx. Chi-Square & 283.970 \\
\hline & df & 28 \\
\hline & Sig. & .000 \\
\hline
\end{tabular}

From Table 2, it very well may be induced that the examination of Kaiser-Meyer-Olkin (KMO) statistics is 0.637 , indicating the sufficient items for each factor in the questionnaire.

Bartlett's test of sphericity gave the 'p' value $(0.000)$ which is less than 00.05 , indicating that the correlation matrix is significantly different from an identity matrix, in which correlations between variables were all zero. It may also be noted that the sample size of 100 is more than 5 times the number of variables, that is 8 . All the above results legitimize the utilization of factor analysis for this study.

Table 3: Total variance described

\begin{tabular}{|c|c|c|c|c|c|c|c|c|c|}
\hline \multicolumn{10}{|c|}{ Total Variance Described } \\
\hline \multirow[b]{2}{*}{ 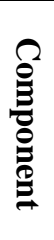 } & \multicolumn{3}{|c|}{ Preliminary Eigenvalues } & \multicolumn{3}{|c|}{ Isolation Sums of Squared Loadings } & \multicolumn{3}{|c|}{ Gyration Sums of Squared Loadings } \\
\hline & $\mathscr{E}$ & 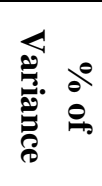 & 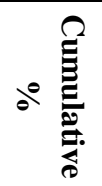 & $\mathscr{\Xi}$ & 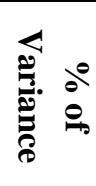 & 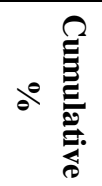 & $\mathscr{E}$ & 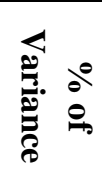 & o9 \\
\hline
\end{tabular}




\begin{tabular}{|l|c|c|c|c|c|c|c|c|c|}
\hline 1 & 3.132 & 39.148 & 39.148 & 3.132 & 39.148 & 39.148 & 2.209 & 27.615 & 27.615 \\
\hline 2 & 1.398 & 17.471 & 56.620 & 1.398 & 17.471 & 56.620 & 2.057 & 25.717 & 53.332 \\
\hline 3 & 1.182 & 14.771 & 71.391 & 1.182 & 14.771 & 71.391 & 1.445 & 18.058 & 71.391 \\
\hline 4 & .830 & 10.371 & 81.762 & & & & & & \\
\hline 5 & .638 & 7.969 & 89.731 & & & & & & \\
\hline 6 & .345 & 4.310 & 94.041 & & & & & & \\
\hline 7 & .290 & 3.620 & 97.661 & & & & & & \\
\hline 8 & .187 & 2.339 & 100.000 & \multicolumn{7}{|c|}{ Isolation Method: Principal Element Analysis. } \\
\hline \multicolumn{80}{|c|}{} \\
\hline
\end{tabular}

The factor is a linear combination of various variables. From Table 3, it was inferred that there were three factors with eigenvalues greater than 1 . The total variance explained by these three parts is 71.391 percent. These three points explained most of the variations in the original set of data. Cut-off point 00.60 was chosen to decipher the outcomes from Table 4. Using this cutoff point, the variables corresponding to factor 1 having a factor loading of 0.60 or above were processing and employee behavior.

Further, the variables corresponding to factor 2 for which the factor loading greater than 0.60 were interest rate and guarantee. Similarly, variables corresponding to factor 3 having a factor loading of 0.60 or above were loan conditions and insurance coverage. These grouped variables under factors $1,2, \& 3$ were assigned names in the accompanying segment.

\subsection{Naming of factors}

Depend on the similarities among the group variables, three factors were given their names as follows:

1) Factor 1 comprising of processing and employee behavior were named as Service Delivery.

2) Factor 2 comprising of interest rate and guarantee were named as Terms \& Conditions.

3) Factor 3 comprising of loan conditions and insurance coverage were named Safety \& Security of Fund.

\section{Managerial implications}

Rested on the study under various heads managers of NBFCs should prudently aim at capturing all the three factors viz. service delivery, terms and conditions, and safety \& security of funds in their marketing plan.
Table 4: Rotated element matrix

\begin{tabular}{|c|c|c|c|}
\hline \multicolumn{4}{|c|}{ Rotated Element Matrix ${ }^{a}$} \\
\hline & \multicolumn{3}{|c|}{ Component } \\
\hline & 1 & 2 & 3 \\
\hline Loan Conditions & -.027 & -.183 & .898 \\
\hline InterestRate & .323 & .805 & -.069 \\
\hline InsuranceCoverage & .496 & .332 & .627 \\
\hline Guarantee & .174 & .900 & .017 \\
\hline Installment & .584 & .406 & -.083 \\
\hline ShopDesign & -.108 & .492 & .451 \\
\hline Processing & .883 & -.021 & .166 \\
\hline EmployeeBehaviour & .834 & .219 & -.053 \\
\hline \multicolumn{4}{|c|}{$\begin{array}{l}\text { Isolation Method: Principal Component Analysis. } \\
\text { Spinning Method: Varimax with Kaiser Normalization. }\end{array}$} \\
\hline a. Spinning & ed in 6 & ations. & \\
\hline
\end{tabular}

\section{Limitations and future research direction}

This work was restricted to the size of the sample. The sample was taken from the different areas of Ranchi city only. Likewise, research was confined to distinguishing the major points affecting the superior of NBFC for availing consumer durable credits, yet the study could not explore the general connection between the given factors and the variables influencing the decision of NBFCs in the above research environment. A conceptual model has been proposed in the following section. It is recommended that further investigation can be completed to distinguish the significant variables influencing the evaluation of NBFCs by using confirmatory points analysis.

\section{Conceptual model based on the outcome}

A conceptual model has been built on the arbitrament of the study. 
VARIABLES

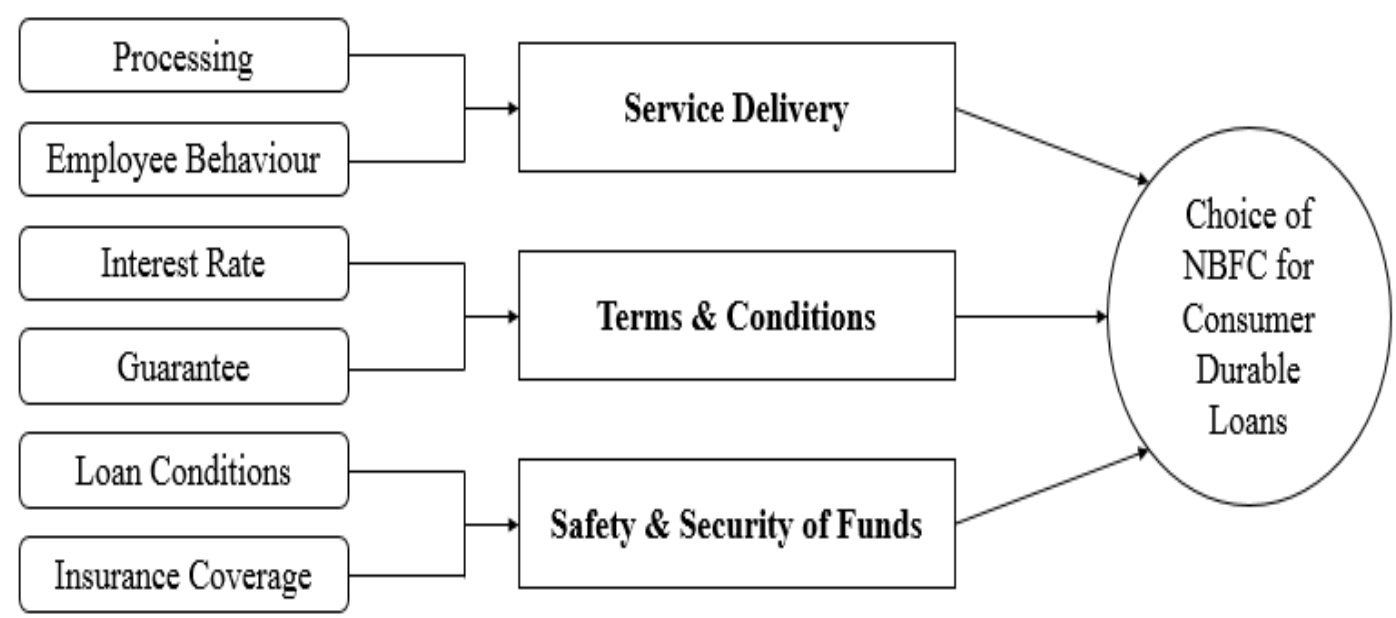

Fig 2: Variables and Factors in the choice of NBFC for CDLs.

\section{CONCLUSION:}

The arbitrament of the work would help marketing honchos to understand the consumer's preferential criteria used in selecting NBFCs for CDLs. Such psychographic preferences criteria help them formulating and implementing suitable marketing policies to gain a completive advantage over their competitors. The investigation reasons that there were three main considerations viz, service delivery terms and conditions and safety and security of funds that influences the choice of NBFCs for availing CDLs. The study recommends that supervisors of NBFCs should zero in on creating an administration conveyance framework, which is more clients friendly and affordable.

\section{ACKNOWLEDGMENT:}

The completion of this research article could not have been possible without the participation and assistant of so many people whose names may not all be enumerated. Their supports are sincerely admire and gratefully acknowledged. However, we would like to express our deep appreciation and indebtedness to Deeba Khan and, Md Haroon Rashid for their endless support, kind, and understanding spirit during our article preparation.

\section{CONFLICTS OF INTEREST:}

The authors declare there is conflicts of interest in the present work and also publish it in any journal.

\section{REFERENCES:}

1) Akter S. (2020). Women employment opportunity on SMEs sector: Bangladesh perspective, Int. J. Manag. Account. 2(5), 105-118. https://doi.org/10.34104/ijma.020.01050118

2) Aliero, H.M., Aliero, I.H. and Zakariyya'u, S. (2018). What determines customers' choice of a bank? Evidence from Sokoto-Nigeria. Journal of Banking and Finance Management, 1(1), pp.61-69.

https://www.researchgate.net/profile/Haruna_Ali ero2/publication/328233333

3) Allaire, Y. (1972). Some marketing thoughts on competition between banks and near banks. Institute of Canadian Bankers Review, 5(1), p.6.

4) Almossawi, M. (2001). Bank selection criteria employed by college students in Bahrain: an empirical analysis. International journal of bank marketing. Available at -

https://www.emerald.com/insight/content/doi/10. $\underline{1108 / 02652320110388540 / \mathrm{full} / \mathrm{html}}$

5) Amin MR. (2020). Human capital investment and its impact on firm's performance: a study on private commercial banks in Bangladesh, Can. J. Bus. Inf. Stud., 2(4), 66-74. https://doi.org/10.34104/cjbis.020.066074 
6) Atmadip Ray, Writankar Mukherjee, (2019). Banks' consumer durable loan business shrinks 75\%. Economic Times, Available at https://economictimes.indiatimes.com/industry/b anking/finance/banking/banks-consumer-durab le-loan-business-shrinks-75/articleshow/68618 109.cms

7) Boyd, W.L., Leonard, M. and White, C. (1994). Customer preferences for financial services: an analysis. International Journal of Bank Marketing.

https://www.emerald.com/insight/content/doi/10. 1108/02652329410049562/full/html

8) Durable goods. (n.d.). In Oxford Learner Dictionary. Available at from -

https://www.oxfordlearnersdictionaries.com/defi nition/english/durable-goods

9) Erol, C., Kaynak, E. and Radi, E.B. (1990). Conventional and Islamic banks: patronage behaviour of Jordanian customers. International Journal of Bank Marketing. https://www.emerald.com/insight/content/doi/10. 1108/02652329010004231/full/html

10) Frangos, C.C., Fragkos, K.C., Sotiropoulos, I., and Valvi, A.C. (2012). Factors affecting customers' decision for taking out bank loans: A case of Greek customers. Journal of Marketing Research \& Case Studies, 2012, p.1. https://www.researchgate.net/publication/266011 $\underline{499}$

11) Haron, S., Ahmad, N. and Planisek, S.L. (1994). Bank patronage factors of Muslim and non-Muslim customers. International Journal of Bank Marketing. Available at https://www.emerald.com/insight/content/doi/10. $\underline{1108 / 02652329410049599 / \mathrm{full} / \mathrm{html}}$

12) Hedayatnia, A. and Eshghi, K. (2011). Bank selection criteria in the Iranian retail banking industry. International Journal of Business and Management, 6(12), p.222.

https://pdfs.semanticscholar.org/e0c7/0b8265db8 63932e5fc97befbbe6423950e5f.pdf

13) Holstius, K. and Kaynak, E. (1995). Retail banking in Nordic countries: the case of Finland. International J. of Bank Marketing. https://www.emerald.com/insight/content/doi/10. $\underline{1108 / 02652329510098873 / \mathrm{full} / \mathrm{html}}$

UniversePG I www.universepg.com
14) Home Credit India Retains the first Position in Small Ticket Consumer Durable Loans (2018, December 21). Business Standard.

https://www.business-standard.com/article/newsani/home-credit-india-retains-first-position-insmall-ticket-consumer-durable-loans-11812210 0961_1.html

15) Hoque MT, Alam J, Burman SD, and Alam QN. (2020). Impact of macroeconomic and bank specific variables on spread of interest rate: a study of listed commercial banks in Bangladesh, Can. J. Bus. Inf. Stud., 2(6), 148156.

https://doi.org/10.34104/cjbis.020.01480156

16) IBEF (India Brand Equity Foundation), (2018). Consumer Durables. Available at https://www.ibef.org/download/Consumer-Dur ables-Report-Apr-20181.pdf

17) Junior, A.D., Osei, B.A. and Petershie, B. (2013). Factors Affecting Customers Choice of Retail Banking in Ghana. International J. of Research in Social Sciences, 3(1), pp.37-44. http://www.ijsk.org/uploads/3/1/1/7/3117743/4_ economics.pdf

18) Kamakodi, N. and Khan, B.A. (2008). An insight into factors influencing bank selection decisions of Indian customers. Asia Pacific Business Review, 4(1), pp.17-26. https://journals.sagepub.com/doi/abs/10.1177/09 7324700800400102

19) Laroche, M., Rosenblatt, J.A. and Manning, T. (1986). Services used and factors considered important in selecting a bank: an investigation across diverse demographic segments. International Journal of Bank Marketing.

https://www.emerald.com/insight/content/doi/10. 1108/eb010771/full/html

20) Mahmud A, and Rahman MH. (2020). Evaluation and comparison of financial soundness of islamic and conventional private commercial banks in Bangladesh: a CAMEL approach, Can. J. Bus. Inf. Stud., 2(6), 129-140. https://doi.org/10.34104/cjbis.020.01290140

21) Rahaman, M.M., Murad, S.W. and Asaduzzaman, M. (2015). Factors Affecting Customer Choice of Commercial Banks in Bangladesh. https://www.researchgate.net/profile/S_M_Woah id_Murad/publication/317596951 
22) Rao, S. and Sharma, D.R. (2010). Bank selection criteria employed by MBA students in Delhi: An empirical analysis. Journal of business studies Quarterly, 1(2), pp.56-69.

https://papers.ssrn.com/sol3/papers.cfm?abstract _id=1597902

23) Ray, S., Miglani, S. and Paul, S. (2018). The growing importance of consumer finance for financial inclusion in India (No. 367). Working Paper. Available at -

https://www.econstor.eu/handle/10419/203701

24) Rehman, H.U. and Ahmed, S. (2008). An empirical analysis of the determinants of bank selection in Pakistan: A customer view. Pakis- tan Economic and Social Review, pp.147-160. Available at -

https://www.jstor.org/stable/25825333?seq=1

25) Singh, D., Sandhu, N. and Singh, H. (2013). Bank Choice Criteria: An Empirical Study of Youth in North India. In International Conference on Management and Information Systems, 22, p. 24. Available at http://www.icmis.net/icmis13/icmis13cd/pdf/T31 98-done.pdf

26) Top 5 NBFCs for Consumer Durable Loans in India (2018). Available at https://www.mymoneystore.in/top-5-nbfcs-forconsumer-durable-loans-in-india/

Citation: Khalid MS, Hans A, Arefin MS, and Hossain MR. (2021). Assessment of the heterogeneity influencing the superior of non-banking finance company for assisting consumer durable loans, Can. J. Bus. Inf. Stud., 3(1), 14-21. https://doi.org/10.34104/cjbis.021.014021 () 